Cemiostoma Wailesella. Apparently common among Genista tinctoria, in meadows.

Bucculatrix maritima. Most abundant in salt-marshes. Sometimes the tiny white-ribbed cocoons may be seen on almost every blade of the wiry grass which grows among the Aster in the mud.

Although this list is fairly long, it must not be taken to imply that Tineina are well represented here; the contrary is the fact. The company may be select, but it certainly is not numerous, and the number of usually common species which here seem to be rare or absent, is really extraordinary. Perhaps this is only what may be expected on the mountain lime-stone.

Pembroke: 25th March, 1878.

\title{
NEW GENERA AND SPECIES OF LONGICORN COLEOPTERA.
}

BY H. W. BATES, F.L.S.

\section{Cyrtognathus planicollis, $n$. $s p$.}

Oblongus, minus convexus, niger, subnitidus, subtiliter coriaceus: capite antice verticali; mandibulis apicem versus dilatatis; thorace valde transversali, plano, subtilissime punctulato, lateribus anticis fortiter bispinosis, angulo postico etiam dentato, acuto; elytris apice ad suturam breviter spinosis, suprà subtiliter punctulatis et obsolete bicostatis: pedibus gracilibus, femoribus tibiisque subtus denticulatoasperatis, tarsorum articulo penultimo anguste bilobo.

§. Antenna corpori longitudine aquales, 12-articulata, articulo $3^{\text {io }}$ valde elongato, lineari, compresso, articulis $3-5$ subtus denticulatis, $3-11$ apice incrassatis, et extus paulo productis.

Long. 18 lin.

Northern Borneo (Mr. Everett).

Nearest allied to C. granulosus (Thoms.), but much smaller and less convex, with thorax still flatter on the disc. The mandibles also are quite different in shape, being gradually dilated from the base to the hooked apex, and plane above. The penultimate tarsal joint has in $M$. granulosus rounded lobes, but in $C$. planicollis, narrow and pointed lobes, more so than in $C$. forficatus. The third antennal joint is greatly elongated, and beneath denticulated, in both species, but in $C$. planicollis it has (with the much shorter 4th joint) the further peculiarity of being flattened.

\section{Hoplideres Nyass.e, $n . s p$.}

Late oblongus, parallelogrammicus, suprà opacus, ơ fulvo-castaneus, $q$ niger : capite grosse reticulato-punctato; thorace lato, transversim quadrato, lateribus fere ut in H. spinipenne acute 5-spinosis; elytris alutaceo-opacis, et subtiliter creberrime punctulatis, basi grossius intricato-punctatis, lateribus infra humeros paulo serratis, apice ad suturam simplicibus: corpore subtus fere nudo, alutaceo-punctulato.

Antennce maris corpore paulo longiores; articulis linearibus, apice haud spinosis, sparsim punctatis: famina corpore triente breviores.

Long. 18 lin. 
Belongs undoubtedly to this genus, although the general form of body is different; the elytra especially being parallelogrammical, convex, and with a considerable posterior declivity, whilst in the other two known species they are somewhat dilated beyond the middle, with expanded lateral margins and very gradual posterior declivity. The $\delta$ is of a tawny-chestnut hue, paler on the elytra, and the of dull sootyblack; but I suspect the $\delta$ specimen to be somewhat immature. The explanated lateral margins of the thorax are still broader than in $H$. spinipennis, and in the $\delta$ are separate from the dise by a rather distinct groove: there is also a distinct dorsal channel in this sex.

Lake Nyassa ; discovered by Mr. E. D. Young, R.N.

\section{Cacosceles Lacordatrei, n. $s p$.}

C. Edipus, Lac. Genera, viii, p. 65. Atlas, pl. 82, f. 1.

The illustrious author of the "Genera" naturally mistook the only species he found in continental collections for the Edipus of Newman, which appears to be an exceedingly rare insect. I acquired, some time ago, from one of Mr. R. Trimen's collections a specimen ticketed "Mossel Bay, S. Africa," which agrees exactly with Newman's description, and is a very distinct species from that of Lacordaire. In the true Edipus the anterior angles of the thorax are dentiform, the antennæ are longer, their joints much more slender and not cupuliform, but simply a little produced on one side at their apices; the colour moreover is wholly dark chestnut, instead of tawny-castaneous as in C. Lacordairei.

The thorax is relatively much broader. With regard to the armature of the sides, it would be better defined as consisting of two broad teeth, the front one of which is obliquely curved, and the second extremely acute, and subspiniform at its apex.

\section{CNETHOCERUS, nov. gen.}

Gen. Priono affinis. Corpustotum maris sericeo-pubescens, femina nudum. Oculi suprà fere contigentes. Antennce maris corpore longiores, articulis 3-11 opacis, dense irregulariter strigosis, apice utrinque acute productis: femina corpore breviores, articulis 3-11 sublinearibus, apice paulo productis, 3-7 lateraliter, 8-11 omnino ut in of strigoso-opacis. Thorax ut in Prionis typicis, transversim quadratus, lateribus tridentatis.

\section{Cnethocerus Messi, $n . s p$.}

Priono coriario paulo magis elongatus, minus convexus; castaneo-fuscus, ơ supra pubescentia incumbenti fulvo-sericeo vestitus; capite thoraceque punctato-scabrosis; elytris obtuse, indistincte, subcostatis, apice late rotundatis, supra basi scabroso-punctatis deinde subtiliter alutuceo-punctulatis : pectore fulvo-hirsuto; abdomine of subopaco, o nitido, irregulariter punctato. 
Hong Kong. From Herr Mess, of Munich. I have since received, for examination, a Japanese specimen, from the Berlin Museum, through E. von Harold.

\section{Derobrachus asperatus, $n . s p$.}

Elongato-oblongus, supra omnino intricato-punctatus, nitidus, niger, elytris maris interdum castaneis; thorace utrinque equaliter trispinoso; elytris nullo modo costatis, apice ad suturam spinosis; antennis $\delta$ corpore paullulum brevioribus; articulis 1 -3 asperato-punctatis, 3 suprà sulcato, 4-5 lateribus, 6-11 omnino, subtiliter acute strigosis : pedibus asperato-granulatis et punctatis : corpore subtus lavi, pectore lateribus punctatis et fulvo-pilosis. Long. ơ, $1 \mathrm{in} .9 \mathrm{lin}$. + , $2 \mathrm{in} .3 \mathrm{lin}$.

Costa Rica, Mt. Irazu, alt. 6-7000 ft. Rogers. Coll. Godman and Salvin, and H. W. Bates.

Synonymical Note.-Paranacus Olivieri, J. Thomson, Rev. et Mag. Zool., 1877, p. 270, = Apotrophus simplicicollis, H. W. Bates, Ent. M. M., vol. xii (1875), pp. 48-49.

Bartholomew Road, Kentish Town : April, 1878.

\section{LIST OF THE HEMIPTERA OF NEW ZEALAND.}

BY F. BUCHANAN WHITE, M.D., F.L.S.

When sufficient material has accumulated, I hope to be able to publish a Synopsis of the Hemiptera of New Zealand; but, as in the meantime I can (thanks to the kindness of Mr. C. M. Wakefield and Captains Broun and Hutton) add considerably to the list presented in 1873 to the Otago Institute by Captain F. W. Hutton, it may not be out of place to give now an account of our present knowledge of the New Zealand Hemiptera.

\section{HETEROPTERA.}

\section{Tribe SCUTATA.}

In Captain Hutton's list referred to above, fifteen species of this tribe are reported. The next and only other list of New Zealand Hemiptera that I have seen is in the concluding part of the Insects of the royage of the Erebus and Terror, published by Mr. Butler in 1874, in which eleven Scutatce are mentioned, two of the names in Captain Hutton's list having been reduced to synonyms, and two others not being mentioned at all. In the following list, four of the names of species mentioned by Captain Hutton are considered as synonymic; but I am able to add two species to the list. In cases where I have seen no New Zealand examples of the species, I give the authority for 


\section{$2 \mathrm{BHL}$ Biodiversity Heritage Library}

Bates, Henry Walter. 1878. "New genera and species of longicorn Coleoptera." The Entomologist's monthly magazine 14, 272-274. https://doi.org/10.5962/bhl.part.22830.

View This Item Online: $\underline{\text { https://www.biodiversitylibrary.org/item/35879 }}$

DOI: https://doi.org/10.5962/bhl.part.22830

Permalink: https://www.biodiversitylibrary.org/partpdf/22830

\section{Holding Institution}

Smithsonian Libraries

\section{Sponsored by}

Smithsonian

\section{Copyright \& Reuse}

Copyright Status: NOT_IN_COPYRIGHT

This document was created from content at the Biodiversity Heritage Library, the world's largest open access digital library for biodiversity literature and archives. Visit BHL at https://www.biodiversitylibrary.org. 